ISSN 2303-0992

ISSN online 2621-3176

Jurnal Matematika dan Pembelajaran

Volume 7, No. 1, Juni 2019, h. 65-80

\title{
EVALUATION OF THE LEARNING PROGRAM OF MATHEMATICS STUDY PROGRAM AT ISLAMIC INSTITUTE OF MUHAMMADIYAH SINJAI
}

\author{
1)Danial, ${ }^{2)}$ Nurjannah, ${ }^{3)}$ Mirna \\ ${ }^{1,2,3}$ Islamic Institute of Muhammadiyah Sinjai \\ e-mail: dhanyfkbs@gmail.com
}

\begin{abstract}
Abstrak
Penelitian ini bertujuan untuk mendeskripsikan hasil evaluasi pelaksanaan pembelajaran matematika di Lembaga Agama Islam Muhammadiyah Sinjai, di samping penelitian ini untuk mendeskripsikan masalah yang muncul dalam pelaksanaan pembelajaran matematika di Lembaga Agama Islam Muhammadiyah Sinjai yang meliputi perencanaan pembelajaran, implementasi pembelajaran, dan penilaian pembelajaran semester. Instrumen yang digunakan dalam penelitian ini adalah kuesioner, lembar observasi dan, dokumentasi. Subjek penelitian ini adalah dosen matematika yang mengajar di Program Studi Matematika sebanyak 3 dosen yang memiliki latar belakang pendidikan magister berbeda. Teknik analisis data yang digunakan dalam penelitian ini adalah analisis data kualitatif. Hasil penelitian menunjukkan bahwa (1) Evaluasi Konteks, dalam aspek ini menunjukkan bahwa terdapat kesesuaian antara kesiapan sekolah, staf pengajar, dengan tujuan program pembelajaran matematika di Institut Agama Islam Muhammadiyah Sinjai, dikategorikan sangat baik, (2) Input Evaluasi, pada aspek input pembelajaran Matematika untuk mata pelajaran SY, IM dan FT berada dalam kategori baik (B), (3) Evaluasi Proses, dalam aspek proses pelaksanaan pembelajaran matematika untuk mata pelajaran SY dan IM dalam kategori baik dan untuk mata pelajaran FT dalam kategori cukup, (4) Evaluasi Produk, Penilaian pembelajaran matematika oleh guru berdasarkan kurikulum Program Studi dalam mata pelajaran SY, IM dan FT berada dalam kategori cukup.
\end{abstract}

Kata kunci: Evaluasi konteks, input evaluasi, evaluasi proses, evaluasi produk

\begin{abstract}
This study aims to describe the results of evaluating the implementation of mathematics learning at the Islamic Institute of Muhammadiyah Sinjai, in addition to this study to describe the problems that arise in the implementation of mathematics learning at the Islamic Institute of Muhammadiyah Sinjai which includes learning planning, learning implementation, and semester learning assessment. The instruments used in this study were questionnaires, observation sheets and, documentation. The subjects of this study were mathematics lecturers who taught in the Mathematics Study Program as many as 3 lecturers who had different master's educational backgrounds. The data analysis technique used in this study is qualitative data analysis. The results showed that (1) Context Evaluation, in this aspect showed that there was a match between school readiness, teaching staff, with the aim of the mathematics learning program at the Islamic Institut of Muhammadiyah Sinjai, categorized very well, (2) Input Evaluation, on the input aspect Mathematics learning for SY, IM and FT subjects is in a good category (B), (3) Process
\end{abstract}


Evaluation, in the aspects of the process of implementing mathematics learning for SY and IM subjects in the good category and for FT subjects in the sufficient category, (4) Product Evaluation, Assessment of mathematics learning by teachers based on the Study Program curriculum in SY, IM and FT subjects is in the sufficient category.

Keywords: Context Evaluation, Input Evaluation, Process Evaluation, Product Evaluation

Sitasi: Danial, Nurjannah. Mirna. 2019. Evaluation of The Learning Program of Mathematics Study Program at Islamic Institute Of Muhammadiyah Sinjai. Matematika dan Pembelajaran, 7(1), 65-80.

\section{INTRODUCTION}

Quality education basically produces quality human resources. Quality human resources are not created by themselves, but through education that is suitable for children's development. Those who receive education services then become mature humans who have expert qualifications, are skilled, creative, innovative, and have positive attitudes and behaviors. Indonesia's future human quality must be better because the progress of a nation is characterized by its qualified human resources.

Obtaining quality human beings, the role and function of education were very important. Thus education must be directed to form human beings who are qualified, able to compete, possess noble and moral character. Efforts to improve the quality of education, especially for the development of science and technology which at present is extremely rapid, the role of mathematics as a basic science should be perfected. Mathematics as a structured and structured science with a level of difficulty that is tiered, namely lower mastery of mathematics is a requirement for mastering higher mathematics, for example in the development of economics, biology, chemistry, and physics requires mathematics. Because of this role, the basic concepts of mathematics should be mastered as early as possible by the students both the applied aspects and the reasoning aspects.

Implementing mathematics learning properly requires skilled educators to design and manage the learning process that leads to the cognitive, affective and psychomotor domains of students. In general, lecturers in presenting material 
immediately wrote mathematical formulas and immediately assigned students to solve problems. In addition, the lecturer does not provide tangible evidence or examples relating to student life, sometimes a lecturer does not activate his students in manipulating teaching aids on the grounds that they are a waste of time and if the results are the same, so in mathematics learning impressed that lecturers dominated more teaching and learning activities.

The learning process as explained earlier is not suitable to be applied to mathematics learning, because it will hinder the creativity of students in developing their thinking power, while the mathematics material learned is a continuation of the material for further education. The most important thing in teaching mathematics is how to provide a meaningful experience that leaves an impression on students so that students like and enjoy learning mathematics (Heruman, 2010).

Thus, one of the important factors to achieve the goal of education is the learning process carried out, while one of the important factors for the effectiveness of learning is the evaluation factor, both the curriculum and the process and the learning outcomes. Evaluation can encourage students to be more active in learning continuously and also encourage a lecturer to improve the quality of the learning process and can encourage universities to improve the facilities and quality of university management.

By conducting an evaluation, it is hoped that it will be known whether learning planning, implementation of learning needs to be improved. As the role of evaluation, namely formal evaluation holds an important role in education, among others, providing information that is used as a basis for improving educational materials and programs by Worten, Blaine, and James R, Sanders, 1987 (Tayibnapis, 2008: 2).

There are several studies on learning evaluation. One of them is the research conducted by Mawarsari and Martyana Prihaswati (2014) with the title of research on Evaluation of Mathematics Learning Using the CIPP Model in Pursuit of Package B. The results of the study indicate that to produce a mathematical learning evaluation process that is maximal and in accordance with the evaluation 
objectives, it is necessary planning and design evaluation of the mathematics learning process carefully.

Another study was conducted by Hakim and Mustaji (2013) entitled Evaluation of the Learning Process at the Fululay Darul Ilmi School in Surabaya. The results of this evaluation study explain that the learning process of the Fullday Darul Ilmi Surabaya Elementary School mathematics seen in the Context Assessment obtained $t$ count $>t$ table $(0.75>0.349)$ then categorized as reliable. In the Assessment of Input obtained tcount $>t$ table $0.77>0.349$ then categorized as reliable and for craft, students said enough. Process assessment is obtained tcount> $\mathrm{t}$ table $(0.64>0.349)$ then it is categorized as reliable, and the addition of learning time can be said to be good. Assessment of results obtained $t$ count $>t$ table (24.6> 2.04) this shows that the learning outcomes of class 6 students experienced a significant increase after following the mathematics learning process.

The two studies mentioned above, only evaluating at the implementation stage of learning alone do not examine in-depth about the evaluation of learning which covers the dimensions of context, input, process and, product. Besides, the two studies above were only carried out at the elementary and package B level so that research needs to be conducted on the evaluation of learning at a high level, namely the University or Institute level.

To obtain the right results and information regarding the implementation of mathematics learning at Islamic Institut of Muhammadiyah Sinjai by conducting a program evaluation, the researchers chose the CIPP evaluation model. This CIPP model is one of several evaluation techniques for an existing program. This model was developed by one of the evaluation experts, Stufflebeam which was developed in 1971 based on four dimensions namely context dimensions, input dimensions, process dimensions, and product dimensions. Evaluation of this model intends to compare the performance of various dimensions of the program with many specific criteria, to finally arrive at a description and decision regarding the strengths and weaknesses of the program being evaluated. This evaluation model has advantages such as its dynamic system, more comprehensive than other models and has a 
holistic approach in its evaluation process which aims to provide a detailed and broad picture of a project, starting from the context until the implementation process.

The reason for choosing this model to evaluate the implementation of mathematics learning is because this model is fundamental, comprehensive, and integrated. It is fundamental because it covers the core objects of the curriculum, namely, goals, material, learning processes, and evaluation itself. Comprehensive because evaluation is also focused on all parties involved in educational practices and implementation of the curriculum. While integrated because the evaluation process involves all parties involved in the practice of education, especially students.

Evaluation comes from the word evaluation (English). The word is absorbed into the vocabulary of the Indonesian language to maintain the original word with a slight adjustment of Indonesian pronunciation to "evaluation". The term "judgment" is a noun of "value". The definition of "measurement" refers to the activity of comparing something with a certain unit of measure. So that Arikunto and Abdul Jabar (2014: 2) reveal the notion of evaluation is "activity to gather information about the workings of something, which then information is used to determine the right alternative in making a decision".

The definition of evaluation proposed by Stufflebeam places evaluation as an activity that is part of management. Therefore, evaluation aims to formulate what must be done, gather information, and present information that is useful in setting alternative decisions. Cronbach (Hasan, 2008: 38) extends the field of study not only to what is happening and ongoing but also to the impact of a curriculum. Meyer is a person who has the same view as Cronbach. The definition of curriculum evaluation proposed by Meyer (Hasan, 2008: 38) includes aspects of curriculum implementation and the impact of the curriculum in the scope of curriculum evaluation.

According to Scriven (Hasan, 2008: 46) evaluation can have a formative 
function, evaluation is used for improvement and development of ongoing activities (programs, people, products and so on). The summative function of evaluation is used for accountability, information, selection, or continuation. So evaluation should help the development of implementation, the need for a program, program improvement, accountability, selection, motivation, increase knowledge and support from those involved.

Based on the above opinion, the evaluation can function for policymakers, policy implementers, as well as for other parties outside of the program takers and implementers. In the learning process, the main purpose is to evaluate to get accurate information about the level of achievement of learning objectives for students so that they can continue the next action.

According to Arikunto and Abdul Jabbar (2014), there are several program evaluation experts known as inventors of program evaluation models such as Stufflebean, Metfessel, Michael Scriven, Stake and, Glaser. Kaufman and Thomas distinguish the evaluation model into eight, namely:
a) Goal Oriental Evaluation Model
b) Goal Fase Evaluation Model
c) Formatif-Sumatif Evaluation Model
d) Responsive Evaluation
e) Countenance Evaluation Model
f) CIPP Evaluation Model
g) CSE-UCLA Evaluation Model
h) Evaluation on Quality and Output of Learning iscrepancy Evaluation Model

The CIPP model with the components of context, process, product, is the result of work on the research team, who are members of a USA Phi Delta Kappa committee organization which was known by Daniel Stufflebeam. The CIPP model is in principle consistent with the definition of evaluation of educational programs proposed by the committee about levels to describe achievement and provide information for alternative decision making. 
This CIPP evaluation model consists of 4 letters described as follows:

a) Contect evaluation to serve planning decision. An evaluator must be careful and keen to understand the context of the evaluation relating to planning decisions, identifying needs, and formulating program objectives.

b) Input Evaluation structuring decision. Everything that affects the evaluation process must be prepared correctly. This evaluation input will assist to be able to organize decisions, determine the resources needed, look for various alternatives to be made, determine a mature plan, make a strategy that will be carried out and pay attention to work procedures in achieving it.

c) Process evaluation to serve implementing decision. In evaluating this process is related to the implementation of a program. Many questions are answered in the process of implementing this evaluation. For example, does the plan have been made by the implementation in the field? Is there something that must be improved in the program implementation process? Thus the program implementation process can be monitored, monitored, or even corrected.

d) Product evaluation to serve recycling decision. Results evaluation is used to determine what decisions will be made next. What benefits do people feel related to the program being rolled out? Does it have the influence and impact of the program? Evaluation of results relates to the benefits and impacts of a program after careful evaluation. Benefits of this model for decision making and accountability for a program to the community. The stages of evaluation in this model are delineating, acquisition or finding (obtaining), and providing for decision-makers.

Learning is a process of change, namely changes in behavior as a result of interaction with the environment in fulfilling their life needs. Behavior change occurs because it is preceded by the process of experience, from experience to experience that causes the process of change. These changes are not only related to the addition of knowledge but also skills, attitudes, self-esteem, character, and 
adaptation. Learning is not only subjects but also a compilation, habits, perceptions, pleasures or interests, social adjustments, various other skills and ideals (Hamalik in Wibowo, 2013: 17). Thus learning is a business process carried out by individuals to obtain a change in new behavior as a whole, as a result of the experience of the individual itself in interaction with the environment.

Learning is an activity that involves lecturers / educators and students in terms of plurality, on the one hand students strive to be able to achieve educational goals and on the other hand lecturers/educators strive so that students can achieve these goals and in achieving them can be beneficial for students (Wibowo, 2013: 21)

Mathematics according to history and its realization is knowledge, this can also be seen from the origin of the words of mathematics itself. The term mathematics comes from the Latin mathematic, which was originally taken from the Greek word, mathematic which means the science or knowledge previously closely related to the mathanein word which means learning (to learn). So, based on the origin of the word mathematics itself originally means knowledge obtained from the learning process (Gie, 1993: 5).

Based on the statements of experts above, it can be concluded that mathematics is a science of logical thinking methods in the study of patterns or relationships of ideas/concepts and abstract structures arranged hierarchically. To be able to understand the structure and relationships needed mastery of the concepts contained in mathematics. This learning of mathematics is learning the concepts and structures contained in the materials being studied.

University mathematics is part of mathematics as a science chosen based on the importance of developing the thinking and personality abilities of students and the interests of the development of science and technology, need to always be in line with the demands of students' interests to face the challenges and demands of future life.

Based on the above definition, it can be concluded that university mathematics is mathematics that has been sorted out and adjusted to the stages of 
the intellectual development of students, and is used as a means of developing thinking skills for students.

The curriculum of the study program is a curriculum that must be owned by each study program, one of which is a mathematics study program. The thing that became a press point in the curriculum of this study program was the improvement and balance of soft skills and hard skills which included aspects of competence of attitudes, skills and, knowledge.

The curriculum of the study program seeks to further instill values that are reflected in attitudes that can be directly proportional to the skills acquired by students with thorough knowledge in the university. In other words, soft skills and hard skills can be embedded in a balanced, side by side and can be applied in everyday life (Fadillah, 2014). With the curriculum of the study program, it is hoped that students can have attitudes, skills, and knowledge competencies that increase and develop by the level of education that has been occupied so that they will be able to influence and find success in the next life.

Based on this description the author tries to evaluate mathematics learning with its relation to the study program curriculum. With this research, it is expected to be known about the planning, implementation and, evaluation conducted by lecturers in the application of the study program curriculum. Therefore, the author took the research title: "Evaluation of Mathematics Learning Implementation at Islamic Institut of Muhammadiyah Sinjai".

\section{METHOD}

This research includes the type of evaluation research that uses a descriptive quantitative approach, namely research with a picture or painting relating to the problems that arise in the present, namely the implementation of mathematics learning. The data collection technique in this study was conducted through a questionnaire method with the instrument being a checklist (checklist) and an open questionnaire in the form of essay questions, observation sheets and, documentation.

The data analysis technique used in this study is the analysis of qualitative 
data to process information obtained by researchers in the form of questionnaire results and observations about evaluating the implementation of mathematics learning at Islamic Institut of Muhammadiyah Sinjai. By what was stated by Miles and Huberman in (Sugiyono, 2014: 337) suggests that the activities in qualitative data analysis are carried out interactively and continue until it is complete so that the data is saturated.

Analysis of the data used in this study are as follows:

1. Comparing the results of the questionnaire understanding of the lecturer and the questionnaire on the implementation of the curriculum of the study program with the implementation of learning.

2. Comparing RPS in meeting I and meeting II by the subject under study, as well as the implementation

3. Comparing observations of implementation with the observation sheet that has been made.

4. Comparing the learning outcomes of students taught by the subject under study

Data that has been obtained from questionnaires provided by lecturers and students will be analyzed how much the compatibility between the criteria and implementation obtained through the instrument. The data obtained from the questionnaire are made criteria by referring to the standard categories set by the Education Standards Agency (BSNP). The categories are as follows:

Table 1: Students Learning Evaluation Categories

\begin{tabular}{|c|c|}
\hline Skor Intervals & Categories \\
\hline $86-100$ & Very High $(\mathrm{VH})$ \\
$70-85$ & High $(\mathrm{H})$ \\
$55-69$ & Intermediate $(\mathrm{I})$ \\
$0-54$ & Low $(\mathrm{L})$ \\
\hline
\end{tabular}

Source: Muhaimin, (2008: 16)

\section{RESULT AND DISCUSSION}

This study uses the CIPP model which is basically by the definition of evaluation of learning implementation to describe the achievement and provision of information for alternative decision making. Broadly speaking, the evaluation of 
the CIPP model includes four types of decisions, namely: a) planning decisions that affect the selection of general goals and specific objectives; b) formation or structuring decisions whose activities include ensuring optimal strategy and process design to achieve objectives that have been derived from planning decisions; c) Implementation decisions, wherein this decision the evaluators seek advice and infrastructure to produce and improve decision making or execution, plans, methods and strategies to be chosen, 4) decisions that have been rearranged which determine which programs need to be continued, continued with modifications, and or totally dismissed on the basis of existing criteria.

\section{Context Evaluation}

In the aspect of Context Evaluation which includes the translation of graduate competency standards, then the background in this case is the state of the university and the population at the university greatly influences the types and strategies used to achieve the learning objectives in Tadris Matematika at Islamic Institut of Muhammadiyah Sinjai.

If the score of each indicator in the context aspect is obtained from the total number of indicators obtained consisting of 3 indicators, so that the total score obtained is divided by a total maximum of 12 then multiplied by $100 \%$, then the final value of the context aspect is $100 \%$. If the numerical data is converted to qualitative data, then based on the standard criteria used in this study, the presentation number means that the aspects of the context in Muhammadiyah Sinjai IAI are categorized as "Very Good" or included in the VG qualification.

\section{Input Evaluation}

Based on the results of the RPS study, the results showed that the RPS that had been made by the SY, IM and, FT subjects had not met the indicators of the RPS compilation components properly. If the score of each indicator in the Input aspect (learning planning stage) is obtained from the total number of indicators obtained consisting of 56 indicators, so the total score obtained from the SY subject is 195 divided by the total maximum of 224 then multiplied by $100 \%$ then the percentage of the final score of the subject SY in the Input aspect is $87.05 \%$. 
Obtaining a score for the subject IM is 180 divided by the maximum score of 224 then multiplied by $100 \%$ then the value of $80.36 \%$ is obtained. Furthermore, for FT subjects in the Input aspect of 168 divided by the maximum total of 224 then multiplied by $100 \%$, the percentage of the final value of FT subjects in the Input aspect was $75 \%$.

If the numerical data is converted to qualitative data, then based on the standard criteria used in this study, the presentation number means that aspects of the learning input in Islamic Institut of Muhammadiyah Sinjai for SY, IM and, FT subjects are all included in the Input aspect categorized as good or qualifying as G.

\section{Process Evaluation}

\section{Review of Process Aspects for SY Subjects at Implementation of First Meeting and Second Meeting}

If the score of each indicator at the implementation stage of learning implementation is lecturer activity, which is obtained from the total score obtained by the indicator consisting of 35 indicators, the total score of the SY subject at the first meeting is 102 divided by the total maximum of 140 then multiplied by $100 \%$ then the percentage of the final SY subject at the learning planning stage is $72.85 \%$. At the second meeting the acquisition score of 106 was divided by the total maximum of 140 then multiplied by $100 \%$, then the percentage of the final value of the SY subject was obtained at the planning stage of $75.71 \%$.

If the numerical data is converted to qualitative data, then based on the standard criteria used in this study, the presentation number means that the implementation of learning in Islamic Institut of Muhammadiyah Sinjai for SY subjects in the implementation of meeting learning I is categorized sufficient (C) but in the implementation of meeting learning II is categorized good (B) in the process aspect.

\section{Results of Assessment of Process Aspects for FT Subjects at Implementation of} First Meeting and Second Meeting

If the score obtained for each indicator at the implementation stage of learning is lecturer activity, which is obtained from the total score obtained by the 
indicator consisting of 35 indicators, the total score obtained from the FT subject at the first meeting is 100 divided by the total maximum of 140 then multiplied by $100 \%$ then the percentage of the final subject FT subject at the implementation stage of learning is $71.42 \%$. At the second meeting, the acquisition score of 104 was divided by the total maximum of 140 then multiplied by $100 \%$, then the percentage of the final value of FT subjects at the implementation stage was $74.28 \%$.

If the numerical data is converted to qualitative data, then based on the standard criteria used in this study, the presentation number means that the implementation of learning in Islamic Institut of Muhammadiyah Sinjai for FT subjects, in the process aspect is categorized as sufficient or included in $\mathrm{C}$ qualification which applies to first and second meeting but the difference is the level of the score only.

\section{Product Evaluation}

If the score of each indicator on the product aspect is obtained, the total score obtained from the indicator consists of indicators, so that the total score of the SY, IM and, FT subjects at each meeting is 11 divided by the total maximum of 16 then multiplied by $100 \%$ then the percentage the final value of the production aspects of the SY, IM and FT subjects was $73.25 \%$.

If the numerical data is converted to qualitative data, then based on the standard criteria used in this study, the presentation numbers means that the implementation of learning in Islamic Institut of Muhammadiyah Sinjai for SY, IM and FT subjects, in product aspects is categorized as sufficient or included in the applicable $\mathrm{C}$ qualification at meetings I and II but the difference is the level of the score only.

The discussion of the results of the study included a description of the learning objectives, learning planning, implementation of learning, and learning outcomes at the Muhammadiyah Sinjai IAI, which are described as follows:

\section{Context Evaluation}

The results of the assessment of the mathematics learning facilities at Islamic Institut of Muhammadiyah Sinjai, based on the reference data from the 
research results indicate that the mathematics learning facilities have not shown good qualifications. The number of rooms with a number of students has been balanced, as well as the arrangement of lecture rooms has been effective because the number of students consists of only 27 students in the classroom in the fourth semester and 18 students in the classroom in semester II, so that the learning process does not appear crowded, not noisy, and easy to set up. However, other facilities such as reference books and campus wifi are still inadequate, so this needs to be considered by lecturers and institutions for the sake of effective learning processes.

\section{Input Evaluation}

The results of the assessment of mathematics learning planning at Islamic Institut of Muhammadiyah Sinjai, have not determined good qualifications because there are still several components in preparing RPS not yet listed in the plans made by the lecturer. Data collection and development of RPS still need attention by lecturers.

\section{Process Evaluation}

\section{Lecturer Performance}

Evaluation of lecturers' performance in this study included (a) mastery of subject matter, (b) management of learning, (c) learning strategies and (e) assessment of learning outcomes. Assessment of lecturer performance is carried out through questionnaires, observation and, documentation.

Based on the results of the assessment obtained data that lecturers in the learning process still need to increase attention in terms of understanding the characteristics of students, managing to learn by utilizing models/methods/approaches/learning strategies that are relevant to the material being taught. At the time of teaching, basically, the lecturer did not pay attention to the use of the model/method/approach/learning strategy. The lecturer only refers to the student book, explaining as necessary then working on the practice questions contained in the textbook.

\section{The motivation for students to take mathematics lessons}

Basically, students are very enthusiastic in following the process of learning 
mathematics. It's just that they sometimes don't believe in what they get, for example, if given a question, they finish but are not sure of the results they get, there are also students who expect answers from their friends. In addition, it was also found in several classes of students who were completing other assignments (not mathematics) when the lecturer gave practice questions.

\section{Product Evaluation}

Evaluation of product aspects in this matter includes evaluating the process and learning outcomes of students. Assessment is a series of activities to obtain, analyze, and interpret data about the process and learning outcomes of students conducted systematically and continuously so that it becomes meaningful information in decision making. Based on the results of the review of each indicator on the production aspects of the instrument, the three subjects have incomplete learning implementation plans, have various forms of assessment but have not been used maximally by the lecturers, so the learning implementation is not in accordance with what has been planned, but student learning outcomes. Learning outcomes taught by SY have a class average of 79.25 with $95 \%$ classical completeness, meaning that $90 \%$ of the total students get a score of completeness 72 and above. While the student learning outcomes taught by FT subjects have an average grade of 75.87 with classical completeness of $90 \%$, meaning that $90 \%$ of the total students get the specified mastery score, 72 and above. And student learning outcomes taught by IM subjects have an average grade of 78.20 with classical completeness of $90 \%$, meaning that $90 \%$ of the students get the specified mastery score, 72 and above.

\section{CONCLUSION}

This study shows that (1) Context Evaluation, in this aspect shows that there is a match between the readiness of the institute, the teaching staff, with the aim of the mathematics learning program at the Islamic Institut of Muhammadiyah Sinjai, categorized very well, (2) Input Evaluation, on the input aspect Mathematics learning for SY, IM and FT subjects is categorized as good (B), (3) Process 
Evaluation, in the aspects of the process of implementing mathematics learning for SY and IM subjects in the good category and for FT subjects in the sufficient category, (4) Product Evaluation, Assessment of mathematics learning by teachers based on the Study Program curriculum in SY, IM and FT subjects is in the sufficient category.

Context evaluation and input evaluation categories are classified as good and good but in the process evaluation and product, evaluation categories should be further improved so that the evaluation results in the Tadris Mathematics study program of the Islamic Institut of Muhammadiyah Sinjai can obtain at least good grades for each category.

\section{REFERENCE}

Abdul, Jabar dan Arikunto, Suharsimi. (2014). Evaluasi Program Pendidikan Pedoman Teoritis Praktis Bagi Mahasiswa dan Praktisi Pendidikan. Jakarta: Bumi Aksara.

Fadillah, M. (2014). Impelentasi Kurikulum program studi dalam Pembelajaran $S D / M I, S Y P / M T S, S Y A / M A$. Yogyakarta: Ar-ruzz Media.

Gie, The Liang. (1993). Filsafat Matematika Bagian Kedua Epistimologi Matematika. Yogyakarta: PUBIB.

Hasan, Hamid. (2008). Dasar-dasar Pengembangan Kurikulum. Bandung: Remaja Rosda Karya.

Heruman. (2010). Model Pembelajaran Matematika di SD. Bandung: Remaja Rosda Karya.

Muhaimin, dkk. (2008). Pengembangan Model Kurikulum Tingkat Satuan Pendidikan (KTSP) pada Universitas Dasar \& Madrasah. Jakarta: PT Raja Grafindo Persada.

Nusantara, Bayu (2017) Evaluasi Pelaksanaan Program Pembelajaran Matematika SD di Kecamatan Bantaeng. S2 thesis, UNY.

Tayibnapis. F.Y (2008). Evaluasi Program dan Instrumen Evaluasi untuk Program Pendidikan dan Penelitian. Jakarta: Rineka Cipta.

Wibowo, Ari. (2013). Implementasi Standar Proses dan Dampak Kognitifnya Dalam Pembelajaran Matematika Oleh Dosen Yang Tersertifikasi dan Belum Tersertifikasi Di 2017/2018p Negeri 21 Makassar, (not published). Makassar: Program Pascasarjana UNM Makassar. 